\title{
ACKNOWLEDGMENTS
}

THE BEST THING ABOUT PUBLISHING a book is that it provides an opportunity to acknowledge publicly the debts that have been incurred in writing it. I first began working on the inscription rehabilitating Virius Nicomachus Flavianus more than a decade ago in a seminar on Roman epigraphy with R. E. A. Palmer at the University of Pennsylvania. He is responsible for much of what I know about epigraphy, and he deserves a share of the credit for whatever is good in this book. He should also be vindicated from responsibility for anything that is not up to his standards.

I spend a great deal of time in this book disagreeing with Alan Cameron. I would regret our disagreements if they had not been so pleasurable and educational for me. Here I would like to thank him for his help. He read the manuscript and gave me supportive criticisms that saved me from many errors. He also let me see a manuscript draft of his forthcoming book, The Last Pagans of Rome. He is witty, erudite, engagingly polemical, and intellectually generous: an exemplary scholar.

My thanks to Josh Ober, Adrienne Mayor, Ian Morris, and Cathy St. John for encouragement and all sorts of aid and comfort when I needed it. Jenny Lynn criticized the manuscript, helped me proofread it, and gave emotional support. My parents and sisters have sustained me, as always. My son Chaz has been inspirational. My daughter Meg arrived just in time to be acknowledged.

In the summer of 199I I received a travel grant from the American Philosophical Society, which made it possible for me to spend the summer in Rome, editing the inscription and familiarizing myself with Roman topography "on the ground." Various scholars, above all Silvio Panciera, helped me locate the inscription and get extended access to it.

In the fall of 1994 I gave a series of lectures for the Program in the Ancient World at Princeton University. In one of these I summarized my interpreta- 
tion of this late antique Roman inscription. Then and later I received much helpful advice from various members of the community of scholars there: Ted Champlin, Jim Luce, Christian Wildberg, and Froma Zeitlin were especially helpful.

I have given outlines of some of the arguments in this book to various audiences around the country. Their reactions have helped refine and modify my views. I single out comments made at lectures at the University of Texas, Austin, and at Stanford University as being particularly helpful.

Many have read the manuscript in part or in whole and have criticized it, sometimes gently, sometimes ferociously. I am appreciative of their time and expertise, and I have always given their suggestions serious considerationeven when I have not adopted them. My gratitude to T. D. Barnes, Peter Brown, Hal Drake, Peter Euben, David Hoy, Bob Kaster, Peter Kenez, Adrienne Mayor, Ron Mellor, Ian Morris, Josh Ober, Jim O’Donnell, and Hayden White.

Countless others have listened to me rant about Flavian and his rehabilitation. Some have responded with interest and to my profit, among them: Harry Berger, Norman Brown, Lowell Edmunds, Arch Getty, David Halperin, David Konstan, Jack Peradotto, and James Packer.

I owe thanks to my colleagues in Classics at UC Santa Cruz as well, as friendly and stimulating a group as I could hope to work with: Karen Bassi, Mary Kay Gamel, John Lynch, Gary Miles, and Dan Selden.

This work was assisted by a grant from the University of California.

In the course of writing this book it has become increasingly clear to me that it is for my father: a token of love and admiration. 


\section{HISTORY AND SILENCE}




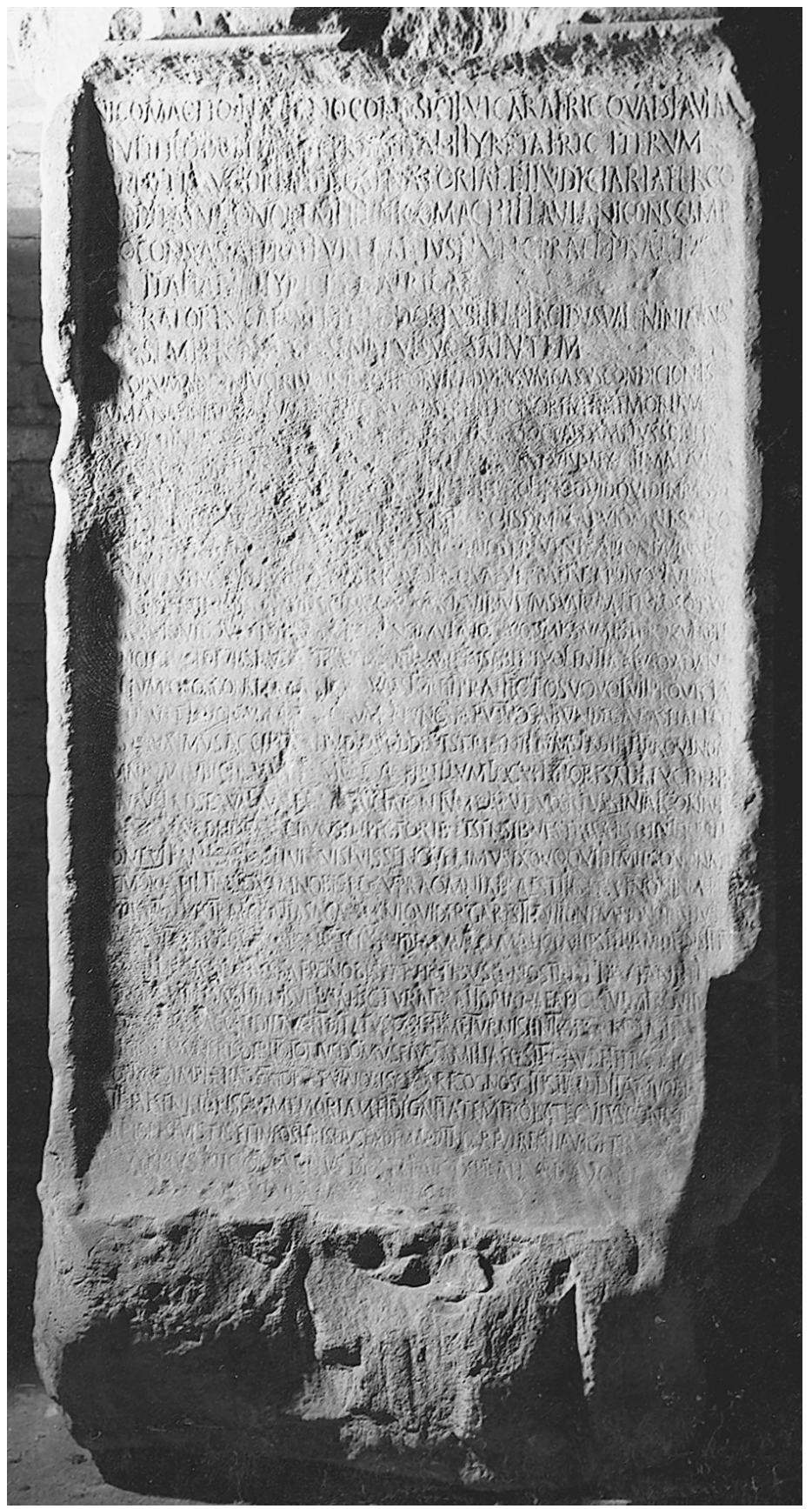

I L L U S . I . CIL 6. I783. Courtesy of Silvio Panciera. 